\title{
Konsep Penataan Ruang Terbuka Publik berdasarkan Pola Aktivitas Pengguna (Studi Kasus Alun-alun Kota Bekasi)
}

\author{
Nur Arief Ramadhan1, Wulan Dwi Purnamasari2, Deni Agus Setyono³ \\ ${ }^{1}$ Mahasiswa Program Studi Sarjana Perencanaan Wilayah dan Kota, Jurusan Perencanaan Wilayah dan Kota, \\ Fakultas Teknik, Universitas Brawijaya \\ 2,3 Dosen Jurusan Perencanaan Wilayah dan Kota, Fakultas Teknik, Universitas Brawijaya \\ nurariefr23@gmail.com
}

\begin{abstract}
ABSTRAK
Alun-alun Kota Bekasi merupakan salah satu ruang terbuka hijau publik yang menjadi pilihan masyarakat Kota Bekasi. Namun, Alun-alun Kota Bekasi masih memiliki permasalahan dalam penyediaan dan kualitas fasilitas untuk menunjang aktivitas para pengguna, seperti belum tersedianya area khusus berdagang, kurangnya fasilitas penerangan dan keamanan, rusaknya area bermain anak dan toilet, serta kurangnya fasilitas parkir. Oleh karena itu, penelitian ini dilakukan untuk merumuskan konsep penataan terhadap fisik Alun-alun Kota Bekasi. Konsep penataan dihasilkan melalui analisis behavior mapping, analisis komparatif, analisis good public space index, dan analisis kano. Analisis behavior mapping digunakan untuk mengetahui persebaran aktivitas dan pelaku aktivitas yang digunakan sebagai input dalam melakukan analisis good public space index. Analisis komparatif dan analisis good public space index digunakan untuk mengukur kualitas fisik dan pemanfaatan ruang di Alun-alun Kota Bekasi. Analisis kano digunakan untuk menentukan priotitas konsep penataan yang dilakukan untuk masing-masing atribut. Hasil dari penelitian ini dirumuskan konsep penataan Alun-alun Kota Bekasi terhadap masing-masing atribut berupa penyediaan fasilitas, perbaikan kualitas fasilitas, dan penyediaan keberagaman fasilitas.
\end{abstract}

Kata kunci: ruang terbuka publik, konsep penataan, analisis kano

\section{ABSTRACT}

Bekasi City Square is one of the public green open spaces chosen by the people of Bekasi City. However, Bekasi City Square still has problems in the provision and quality of facilities to support users' activities, such as the unavailability of trading areas, lack of lighting and security facilities, damage to children's play areas and toilets, and lack of parking facilities. Therefore, this research was conducted to formulate the physical structuring concept of Bekasi City Square. The structuring concept is produced through behavior mapping analysis, comparative analysis, good public space index analysis, and kano analysis. Behavior mapping analysis is used to determine the distribution of activities and activity actors used as input in analyzing a good public space index. Comparative analysis and good public space index analysis are used to measure physical quality and space utilization in Bekasi City Square. Kano analysis is used to determine the priority of the structuring concept carried out for each attribute. The results of this study formulated the concept of structuring the Bekasi City Square on each attribute in the form of provision of facilities, improved quality of facilities, and a diversity of facilities.

Keywords: public open space, concept of structuring, kano analysis 


\section{Pendahuluan}

Ruang terbuka publik didefinisikan sebagai ruang yang dimiliki bersama, tempat masyarakat beraktivitas dalam ikatan komunitas, dan tempat untuk melakukan aktivitas sosial yang melayani kehidupan masyarakat kota (Carr et al. 1992). Kualitas ruang terbuka publik yang baik memiliki indikator berupa responsive places, democratic places, dan meaningful places (Carr et al. 1992). Responsive Places menunjukkan ruang publik harus mampu melayani kebutuhan dan keinginan masyarakat penggunanya. Democratic Places menunjukkan bahwa ruang publik harus dapat melindungi hak individu dan kelompok masyarakat penggunanya. Meaningful Places menunjukkan bahwa ruang publik harus dapat menciptakan kenangan dan arti tersendiri bagi pengguna.

Alun-alun Kota Bekasi merupakan salah satu ruang terbuka hijau publik di Kota Bekasi yang berada di pusat pelayanan Kota Bekasi dan menjadi pilihan masyarakat untuk beraktivitas (RTRW Kota Bekasi 2011-2031). Alun-alun Kota Bekasi terletak di Kelurahan Marga Jaya, Kecamatan Bekasi Selatan. Alun-alun ini terdiri dari area Taman Lalu Lintas, area Lapangan, area Plaza, dan area Taman Kota Bekasi. Namun, sebagai ruang terbuka publik yang pilihan masyarakat Kota Bekasi, Alun-alun Kota Bekasi belum diimbangi dengan ketersediaan fasilitas dengan kondisi yang baik, karena fasilitas pendukung di Alun-alun Kota Bekasi mengalami kerusakan dan kurang dalam penyediaan (LKIP DLH Kota Bekasi, 2019).

Beberapa permasalahan yang terdapat di Alun-alun Kota Bekasi diantaranya: Belum tersedianya fasilitas kios dan area khusus berdagang yang mengakibatkan area plaza \& lapangan dikuasai pedagang kaki lima, kurangnya fasilitas penerangan \& keamanan yang mengakibatkan beberapa area di Alun-alun Kota Bekasi menjadi sepi pengunjung dan rawan terhadap kriminalitas, rusaknya fasilitas bermain anak dan toilet, serta kurangnya fasilitas parkir \& maraknya parkir liar yang mengakibatkan kawasan di sekitar Alun-alun Kota Bekasi menjadi macet saat jam puncak kedatangan para pengunjung.

Penelitian ini yang ditujukan untuk membuat konsep penataan terhadap fisik terhadap masing-masing zona di Alun-alun Kota Bekasi. Terdapat 3 zona yang dapat terbentuk di ruang terbuka publik menurut Irawan et al. (2015), yang pertama adalah zona publik, yaitu zona yang mewadahi aktivitas secara umum dan dapat diakses oleh semua orang tanpa ada Batasan. Kedua adalah zona semi publik, yaitu zona yang memiliki jenis aktivitas yang lebih spesifik dibandingkan dengan zona publik. Ketiga adalah zona privat, yaitu zona yang bersifat tertutup, di mana tidak semua orang dapat mengakses zona ini.

\section{Metode Penelitian}

\subsection{Jenis Penelitian}

Penelitian berjudul "Konsep Penataan Ruang Terbuka Publik berdasarkan Pola Aktivitas Pengguna (Studi Kasus Alun-alun Kota Bekasi)" merupakan jenis penelitian deskriptif kuantitatif. Deskriptif digunakan dalam menjelaskan fenomena ataupun kondisi pelaku aktivitas dan fasilitas yang terdapat di Alun-alun Kota Bekasi pada saat melakukan analisis behavior mapping dan analisis komparatif. Kuantitatif digunakan dalam melakukan perhitungan untuk analisis analisis good public index dan analisis kano.

\subsection{Variabel Penelitian}

Penelitian dilakukan dengan menggunakan 3 variabel, yaitu kualitas fisik ruang terbuka publik, kualitas pemanfaatan ruang terbuka publik, dan persepsi pengguna. Variabel kualitas fisik ruang terbuka publik diukur menggunakan analisis komparatif 
dengan sub variabel ketersediaan fasilitas dan kondisi fasilitas. Variabel kualitas pemanfaatan ruang terbuka publik diukur menggunakan analisis good public space index dengan sub variabel intensitas penggunaan aktivitas, intensitas aktivitas sosial, durasi melakukan aktivitas, keragaman aktivitas, variasi penggunaan aktivitas, dan keberagaman pengguna yang didapatkan melalui observasi menggunakan behavior mapping. Variabel persepsi pengguna diukur menggunakan analisis kano dengan sub variabel access and linkage, comfort and image, uses and activities, dan sociability. Konsep penataan kemudian dihasilkan melalui penentuan zonasi dan tabel persandingan.

\subsection{Penentuan Sampel}

Penentuan sampel menggunakan rumus linear time function dengan total responden sebesar 336 orang. Linear time function merupakan penentuan jumlah sampel berdasarkan estimasi kendala waktu / estimasi lamanya waktu survei (Sari dalam Pattisinai, 2016). Linear time function dipilih dalam menentukan jumlah sampel dikarenakan populasi pada Alun-alun Kota Bekasi yang tidak tetap dan berubah-ubah setiap harinya, sehingga digunakan estimasi waktu survei dalam menentukan jumlah sampel. Penentuan responden dilakukan menggunakan teknik purposive sampling dengan kriteria pengguna Alun-alun Kota Bekasi yang sedang melakukan aktivitas.

\subsection{Behavior Mapping}

Menurut (Sommer dalam Firmansyah, 2016) Behavior Mapping digunakan untuk menggambarkan perilaku dalam peta dengan mengidentifikasikan jenis dan frekuensi perilaku, serta menunjukkan kaitan antara perilaku tersebut dengan wujud perancangan yang spesifik. Analisis behaviour mapping dilakukan dengan cara place centered dengan langkah-langkah sebagai berikut.

a. Membuat sketsa tempat yang meliputi seluruh unsur fisik yang diperkirakan mempengaruhi perilaku pengguna ruang.

b. Membuat daftar perilaku yang akan diamati serta menentukan simbol setiap perilaku.

c. Kemudian dalam kurun waktu tertentu, peneliti mencatat berbagai perilaku yang terjadi di tempat tersebut dengan menggunakan simbol - simbol di peta dasar.

Daftar aktivitas dan simbol masing-masing aktivitas yang akan dilakukan observasi menggunakan behavior mapping pada penelitian ini dapat dilihat sebagai berikut (Tabel 1).

Tabel 1. Daftar Jenis Aktivitas dan Simbol Aktivitas

\begin{tabular}{|c|c|c|c|}
\hline Tipologi aktivitas & Jenis aktivitas & $\begin{array}{c}\text { Simbol untuk } \\
\text { Laki-laki }\end{array}$ & $\begin{array}{c}\text { Simbol untuk } \\
\text { Perempuan }\end{array}$ \\
\hline \multirow{5}{*}{ Aktivitas kontak fisik } & Mengobrol & $\bullet$ & $\Delta$ \\
\hline & Berjualan & - & $\Delta$ \\
\hline & Bermain dengan teman & - & $\Delta$ \\
\hline & Olahraga dengan teman & $\bullet$ & $\Delta$ \\
\hline & Makan Bersama teman & $\bullet$ & $\Delta$ \\
\hline \multirow{6}{*}{ Aktivitas transisi } & Duduk & $\bullet$ & $\Delta$ \\
\hline & Berdiri & $\bullet$ & $\Delta$ \\
\hline & Makan & $\bullet$ & $\boldsymbol{\Delta}$ \\
\hline & Menggunakan HP & $\bullet$ & $\Delta$ \\
\hline & Olahraga & - & $\Delta$ \\
\hline & Memfoto & - & $\Delta$ \\
\hline
\end{tabular}

\subsection{Analisis Komparatif}

Analisis komparatif merupakan analisis yang digunakan untuk mencari jawaban secara mendasar tentang sebab-akibat, dengan menganalisis faktor-faktor penyebab 
terjadinya ataupun munculnya suatu fenomena tertentu. Analisis ini juga dilakukan untuk membandingkan persamaan dan perbedaan dua atau lebih fakta-fakta dan sifat-sifat objek yang di teliti berdasarkan kerangka pemikiran tertentu. Pada Penelitian ini analisis komparatif dilakukan untuk mengetahui kualitas fisik fasilitas di Alun-alun Kota Bekasi yang dilakukan perbandingan antara ketersediaan dan kondisi fasilitas eksiting di Alunalun Kota Bekasi dengan teori dan peraturan terkait penyediaan fasilitas di ruang terbuka publik (Hariyadi et al. 2015).

\subsection{Analisis Good Public Space Index}

Good Public Space Index (GPSI) merupakan analisis terhadap pengguna dan perilaku pengguna ruang luar yang dikembangkan dalam kajian ruang publik terutama untuk menilai respon pengguna ruang terhadap kualitas ruang publik. Parlindungan (2013) mempergunakan beberapa variabel yang dipergunakan untuk mengukur dan menyusun GPSI, antara lain:

a. Intensitas penggunaan, menjelaskan jumlah orang yang terlibat dalam aktivitas pada ruang luar (rumus 1 ).

$$
\text { Intensitas penggunaan }=\frac{\text { Rata-rata jumlah orang }}{\text { Jumlah tertinggi }}
$$

b. Intensitas aktivitas sosial, menjelaskan keberadaan kelompok pengguna pada ruang luar (rumus 2).

$$
\text { Intensitas aktivitas sosial }=\frac{\text { Jumlah orang dalam kelompok }}{\text { Jumlah tertinggi }}
$$

c. Durasi aktivitas, menjelaskan durasi (lama) orang melaksanakan aktivitas pada ruang luar (rumus 3).

Durasi aktivitas $=\frac{\text { Rata-rata waktu }}{\text { Waktu tertinggi }}$

d. Keragaman aktivitas, diukur berdasarkan sebaran aktivitas saat waktu amatan.

e. Variasi penggunaan, mengukur aktivitas tiap jenis aktivitas yang dilaksanakan pada ruang.

f. Keberagaman pengguna, mengukur variasi pengguna berdasarkan usia dan jenis kelamin.

g. Keragaman aktivitas, variasi penggunaan, dan keberagaman pengguna dihitung dengan Simpson's diversity index. Simpson's diversity index adalah teknik yang lazim dipergunakan dalam analisis keanekaragaman hayati dalam ranah ilmu lingkungan (rumus $4 \& 5$ ) .

Simpson's diversity index $=1$

$D=\frac{\sum n(n-1)}{N(n-1)}$

Keterangan:

$\mathrm{D}=$ Keberagaman aktivitas

$\mathrm{n}=$ Jumlah individu dalam kategori tertentu

$\mathrm{N}=$ Jumlah total individu dalam semua kategori

Dasar interpretasi hasil dari GPSI, yaitu: Jika Indeks bernilai 0,00-0,40 masuk ke dalam ketegori rendah, jika indeks bernilai 0,41-0,70 masuk ke dalam kategori sedang, dan jika indeks bernilai 0,71-1,00 masuk ke dalam kategori tinggi (Gumano et al. 2016). 


\subsection{Analisis Kano}

Model Kano yang dikembangkan oleh Dr. Noriaki Kano adalah model yang bertujuan untuk mengkategorikan atribut-atribut dari produk ataupun jasa berdasarkan seberapa baik produk atau jasa tersebut mampu memuaskan kebutuhan pelanggan. Langkah-langkah analisis kano menurut Berger et al. (1993) adalah sebagai berikut.

a. Identifikasi atribut, menentukan atribut yang menjadi objek analisis kano.

b. Penyebaran kuisioner, dilakukan menggunakan 5 skala, yaitu: Suka, Mengharapkan, Netral, Memberi toleransi, dan Tidak Suka. Pertanyaan yang diajukan berupa pertanyaan fungsional dan pertanyaan disfungsional.

c. Pengkategorian atribut, dilakukan untuk mengetahui kategori kano yang didapat oleh masing-masing atribut (Tabel 2).

Tabel 2. Evaluasi Kano

\begin{tabular}{lccccc}
\hline \multirow{2}{*}{ Respon pertanyaan fungsional } & \multicolumn{5}{c}{ Respon pertanyaan disfungsional } \\
\cline { 2 - 6 } & Suka & Sudah seharusnya & Netral & Toleranisi & Tidak suka \\
\hline Suka & $\mathrm{Q}$ & $\mathrm{A}$ & $\mathrm{A}$ & $\mathrm{A}$ & $\mathrm{O}$ \\
Sudah seharusnya & $\mathrm{R}$ & $\mathrm{I}$ & $\mathrm{I}$ & $\mathrm{I}$ & $\mathrm{M}$ \\
Netral & $\mathrm{R}$ & $\mathrm{I}$ & $\mathrm{I}$ & $\mathrm{I}$ & $\mathrm{M}$ \\
Memberi toleransi & $\mathrm{R}$ & $\mathrm{I}$ & $\mathrm{I}$ & $\mathrm{I}$ & $\mathrm{M}$ \\
Tidak suka & $\mathrm{R}$ & $\mathrm{R}$ & $\mathrm{R}$ & $\mathrm{R}$ & $\mathrm{Q}$ \\
\hline
\end{tabular}

Keterangan: $\mathrm{O}=$ =ne dimensional, $\mathrm{M}=$ Must be, $\mathrm{A}=$ Attractive, I= Indifferent, $\mathrm{Q}=\mathrm{Questionable,} \mathrm{R}=$ Reverse (Sumber: Berger et al., 1993)

d. Tindak Perbaikan, menghitung nilai better untuk mengetahui tingkat kepuasan pengguna jika atribut tersedia dan menghitung nilai worse untuk mengetahui tingkat kekecewaan pengguna jika atribut tidak tersedia. Posisi prioritas kategori kano untuk dilakukan penanganan yaitu, Must Be > One dimensional > Attractive > indifferent.

\section{Hasil dan Pembahasan}

\subsection{Behavior Mapping}

Aktivitas pada pagi hari yang dilakukan para pengguna Alun-alun Kota Bekasi saat weekday dan weekend sebagian besar memiliki jenis aktivitas olahraga bersama teman di area lapangan dan area Taman Lalu lintas. Para pengguna memilih berolahraga di area lapangan karena memiliki area luas dan terdapat fasilitas trek lari. Area Taman Lalu lintas juga menjadi pilihan pengguna untuk berolahraga karena terdapat daya tarik berupa Monumen Perjuangan Rakyat Bekasi dan pepohonan yang rimbun.

Aktivitas siang hari yang dilakukan oleh para pengguna Alun-alun Kota Bekasi pada saat weekday dan weekend sebagian besar adalah mengobrol. Para pengguna memanfaatkan pepohonan yang teduh dan tempat duduk di sekitar pepohan yang berada di area Taman Lalu lintas dan area Taman Kota Bekasi untuk melakukan aktivitas mengobrol. Pada saat siang hari para pengguna juga memanfaatkan Alun-alun Kota Bekasi untuk melakukan aktivitas makan siang karena terdapatnya pedagang kaki lima di sekitar lapangan.

Aktivitas pada sore hari yang dilakukan oleh para pengguna Alun-alun Kota Bekasi pada saat weekday dan weekend sebagian besar memiliki jenis aktivitas mengobrol. Pada sore hari mulai terjadi pemusatan aktivitas di area plaza dan lapangan karena mulai datangnya pedagang dengan jumlah yang banyak ke area lapangan dan plaza.

Aktivitas di malam hari yang dilakukan oleh para pengguna Alun-alun Kota Bekasi sebagian besar memiliki jenis aktivitas mengobrol pada saat weekday dan makan bersama teman pada saat weekend. Pada malam hari, pemusatan aktivitas terjadi di area lapangan 
dan area plaza karena terdapat daya tarik berupa hadirnya para pedagang kaki lima dengan jumlah banyak yang menjual aneka makanan dan minuman serta menyediakan tikar yang digunakan oleh para pengguna sebagai tempat untuk berkumpul (Gambar 1).

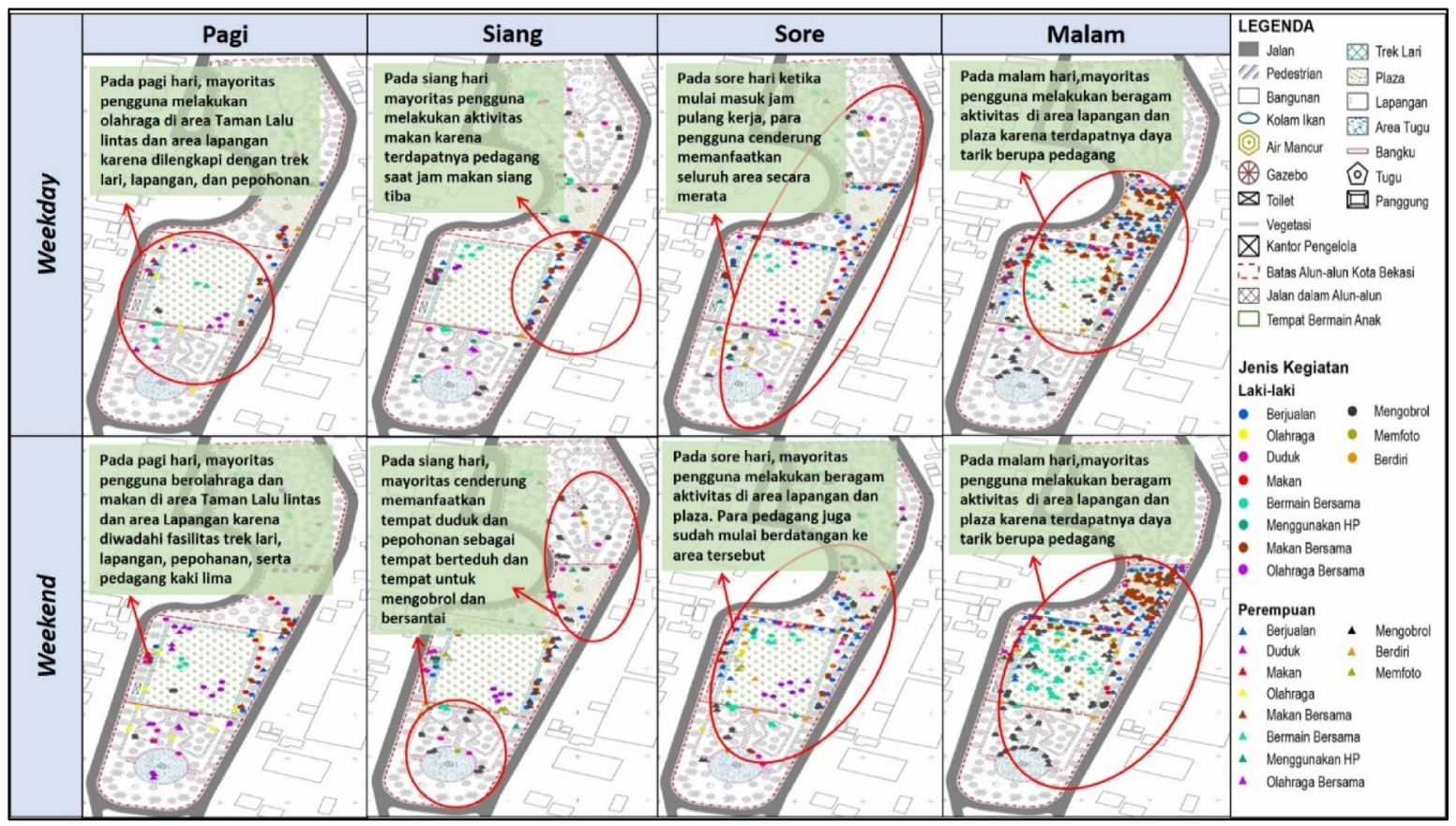

Gambar 1. Peta Behavior Maping di Alun-alun Kota Bekasi

\subsection{Kualitas Fisik Alun-alun Kota Bekasi}

Kualitas fisik Alun-alun Kota Bekasi diukur dengan membandingkan eksisting ketersediaan fasilitas dan kondisi fasilitas pada di Alun-alun Kota Bekasi dengan standar ketersediaan fasilitas dan kondisi masing-masing fasilitas. Skema pengukuran kualitas fisik fasilitas dan hasil kualitas fisik di Alun-alun Kota Bekasi dapat dilihat sebagai berikut (Gambar 2 dan Tabel 3).

\begin{tabular}{|c|c|c|c|c|c|c|c|c|}
\hline \multirow{2}{*}{ FASILITAS } & \multicolumn{4}{|c|}{ STANDAR FASILITAS } & \multicolumn{3}{|c|}{ EKSISTING FASILITAS } & \multirow{2}{*}{ ANALISIS } \\
\hline & Ketersediaan & Kondisi fisik & Keterawatan & Sumber & Ketersediaan & Kondisi fisik & Keterawatan & \\
\hline TOILET & $\begin{array}{l}\text { 1. Jarak } \\
\text { maksimal } \\
\text { toilet dengan } \\
\text { pengguna } \\
\text { yang dilayani } \\
\text { yaitu sejauh } \\
100 \text { meter } \\
\text { 2. Toilet } \\
\text { diletakkan di } \\
\text { area yang } \\
\text { bebas dari } \\
\text { banjir }\end{array}$ & $\begin{array}{l}\text { 1. Toilet } \\
\text { memiliki air } \\
\text { bersih yang } \\
\text { memadai } \\
\text { 2. Toilet } \\
\text { dilengkapi } \\
\text { wastafel, } \\
\text { kran, cermin, } \\
\text { tempat } \\
\text { sabun, } \\
\text { tempat } \\
\text { sampah, } \\
\text { urinal, } \\
\text { penerangan }\end{array}$ & $\begin{array}{l}\text { 1. Dinding } \\
\text { toilet tidak } \\
\text { kotor, kering, } \\
\text { tidak } \\
\text { mengelupas, } \\
\text { dan tidak } \\
\text { terdapat } \\
\text { coretan } \\
\text { 2. Lantai } \\
\text { bebas dari } \\
\text { debu, } \\
\text { retakan, dan } \\
\text { tidak berbau, } \\
\text { dan tidak } \\
\text { kotor }\end{array}$ & $\begin{array}{l}\text { Asosiasi } \\
\text { Toilet } \\
\text { Indones } \\
\text { ia } \\
\text { (2016) }\end{array}$ & $\begin{array}{l}\text { Alun-alun Kota } \\
\text { Bekasi memiliki } \\
4 \text { toilet di area } \\
\text { Taman Kota } \\
\text { Bekasi dan } 1 \\
\text { toilet di area } \\
\text { lapangan. Toilet } \\
\text { berada pada } \\
\text { area yang bebas } \\
\text { banjir dan juga } \\
\text { sudah seseuai } \\
\text { dengan cakupan } \\
\text { pelayanan } \\
\text { sejauh } 100 \\
\text { meter }\end{array}$ & $\begin{array}{l}\text { Toilet di Alun- } \\
\text { alun Kota } \\
\text { Bekasi secara } \\
\text { keseluruhan } \\
\text { belum } \\
\text { dilengkapi } \\
\text { wastafel, kran, } \\
\text { cermin, tempat } \\
\text { sabun, tempat } \\
\text { sampah, } \\
\text { pengering } \\
\text { tangan, urinal, } \\
\text { serta } \\
\text { penerangan. }\end{array}$ & $\begin{array}{l}\text { Toilet di Alun- } \\
\text { alun Kota Bekasi } \\
\text { memiliki kondisi } \\
\text { dinding yang } \\
\text { kotor. Toilet } \\
\text { mengalami } \\
\text { kerusakan pada } \\
\text { bagian kloset, } \\
\text { sehingga kloset } \\
\text { tidak dapat } \\
\text { digunakan oleh } \\
\text { para pengguna } \\
\text { Alun-alun Kota } \\
\text { Bekasi }\end{array}$ & $\begin{array}{l}\text { Secara ketersediaan, toilet telah sesuai } \\
\text { dengan standar, dimana toilet terbebas } \\
\text { dari banjir dan setiap jarak } 100 \text { meter di } \\
\text { Alun-alun Kota Bekasi telah tersedia toilet } \\
\text { Secara kondisi fisik, toilet yang berada di } \\
\text { area Taman Kota Bekasi belum memenuhi } \\
\text { standar. Toilet belum tersedia, wastafel, } \\
\text { kran, cermin, tempat sabun, tempat } \\
\text { sampah, pengering tangan, urinal,dan } \\
\text { penerangan } \\
\text { Secara keterawatan, seluruh toilet di area } \\
\text { taman dan lapangan belum memenuhi } \\
\text { standar karena masih memiliki dinding } \\
\text { yang kotor, lantai yang berdebu dan kotor }\end{array}$ \\
\hline
\end{tabular}

Gambar 2. Contoh Skema Pengukuran Kualitas Fisik 
Tabel 3. Hasil Kualitas Fisik Fasilitas

\begin{tabular}{|c|c|c|c|c|}
\hline \multirow{3}{*}{ Jenis Fasilitas } & \multicolumn{3}{|c|}{ Kesesuaian Kondisi Eksisting dengan Standar Masing-masing } & \multirow{3}{*}{ Kualitas Fisik } \\
\hline & \multicolumn{3}{|c|}{$\begin{array}{ll}\text { Fasilitas } \\
\end{array}$} & \\
\hline & Ketersediaan & Kondisi Fisik & Keterawatan & \\
\hline Toilet & Telah sesuai standar & Belum sesuai standar & Belum sesuai standar & Tidak Baik \\
\hline Tempat Sampah & Belum sesuai standar & Telah sesuai standar & Telah sesuai standar & Tidak Baik \\
\hline Petunjuk arah Jalan & Telah sesuai standar & Belum sesuai standar & Telah sesuai standar & Tidak Baik \\
\hline Papan peringatan & Telah sesuai standar & Telah sesuai standar & Telah sesuai standar & Baik \\
\hline Lampu penerangan & Belum sesuai standar & Belum sesuai standar & Belum sesuai standar & Tidak Baik \\
\hline Jalan & Telah sesuai standar & Belum sesuai standar & Telah sesuai standar & Tidak Baik \\
\hline Pedestrian & Belum sesuai standar & Belum sesuai standar & Belum sesuai standar & Tidak Baik \\
\hline Tempat duduk & Belum sesuai standar & Belum sesuai standar & Telah sesuai standar & Tidak Baik \\
\hline Pagar pembatas & Telah sesuai standar & Telah sesuai standar & Belum sesuai standar & Tidak Baik \\
\hline Pohon & Telah sesuai standar & Belum sesuai standar & Telah sesuai standar & Tidak Baik \\
\hline CCTV & Belum sesuai standar & Belum sesuai standar & Belum sesuai standar & Tidak Baik \\
\hline Trek lari & Belum sesuai standar & Telah sesuai standar & Telah sesuai standar & Tidak Baik \\
\hline Lapangan & Belum sesuai standar & Telah sesuai standar & Telah sesuai standar & Tidak Baik \\
\hline Kios & Belum sesuai standar & Belum sesuai standar & Belum sesuai standar & Tidak Baik \\
\hline Arena bermain anak & Telah sesuai standar & Belum sesuai standar & Belum sesuai standar & Tidak Baik \\
\hline Kolam & Telah sesuai standar & Telah sesuai standar & Belum sesuai standar & Tidak Baik \\
\hline Parkir & Belum sesuai standar & Telah sesuai standar & Telah sesuai standar & Tidak Baik \\
\hline Panggung terbuka & Telah sesuai standar & Belum sesuai standar & Telah sesuai standar & Tidak Baik \\
\hline Transportasi umum & Telah sesuai standar & Telah sesuai standar & Telah sesuai standar & Baik \\
\hline
\end{tabular}

\subsection{Kualitas Pemanfaatan Ruang}

Kualitas pemanfaatan ruang di Alun-alun Kota Bekasi menggunakan analisis Good Public Space Index (GPSI). Hasil kualitas pemanfaatan ruang di Alun-alun Kota Bekasi dijelaskan sebagai berikut (Tabel 4).

Tabel 4. Hasil Perhitungan Good Public Space Index

\begin{tabular}{lcc}
\hline \multicolumn{1}{c}{ Kriteria } & Hasil GPSI & Kategori \\
\hline Intensitas penggunaan aktivitas & 0,58 & Sedang \\
Intensitas penggunaan aktivitas sosial & 0,51 & Sedang \\
Durasi pengguna melakukan aktivitas & 0,84 & Tinggi \\
Keragaman aktivitas & 0,77 & Tinggi \\
Variasi penggunaan aktivitas & 0,84 & Tinggi \\
Keberagaman pengguna & 0,83 & Tinggi \\
\hline
\end{tabular}

Berdasarkan hasil perhitungan GPSI dapat diketahui bahwa intensitas penggunaan aktivitas memiliki hasil 0,58 dan intensitas aktivitas sosial memiliki hasil 0,51 yang masuk dalam kategori "sedang". Masuknya Alun-alun Kota Bekasi ke dalam kategori "sedang" menandakan masih terdapatnya dominasi pengguna yang beraktivitas pada satu waktu tertentu jika dibandingkan waktu lainnya, meskipun dominasi tersebut tidak terlalu signifikan. Hasil tersebut menandakan bahwa Alun-alun Kota Bekasi belum sepenuhnya bersifat demokratis dan responsif bagi para penggunanya.

Hasil perhitungan GPSI terhadap durasi melakukan aktivitas memiliki hasil 0,84, keragaman aktivitas memiliki hasil 0,77, variasi penggunaan aktivitas memiliki hasil 0,84, dan keberagaman pengguna memiliki hasil 0,83 yang secara keseluruhan masuk ke dalam kategori "tinggi". Masuknya Alun-alun Kota Bekasi ke dalam kategori tinggi menandakan sudah beragamnya masing-masing kriteria pembentukn pada saat pagi, siang, sore, dan malam hari. Hasil GPSI yang masuk ke dalam kategori "tinggi" menandakan bahwa masingmasing kriteria pembentuk memiliki sifat yang demokratis karena digunakan oleh individu yang beragam, lebih responsif karena mampu mengakomodasi aktivitas yang beragam, sehingga para pengguna menyukainya karena Alun-alun Kota Bekasi lebih memiliki makna. 


\subsection{Konsep Penataan Alun-alun Kota Bekasi}

\subsubsection{Evaluasi Kano}

Evaluasi kano dilakukan berdasarkan hasil kuisioner dari pertanyan fungsional dan disfungsional yang diajukan kepada para pengguna untuk masing-masing atribut. Hasil evaluasi kano dijelaskan sebagai berikut (Tabel 5).

\section{Tabel 5. Evaluasi Kano}

\begin{tabular}{|c|c|c|c|c|c|c|c|c|c|c|}
\hline Atribut & $\mathbf{0}$ & $\mathbf{A}$ & M & I & $\mathbf{R}$ & $\mathbf{Q}$ & Total & Grade & Better & Worse \\
\hline Kondisi jalan Alun-alun Kota Bekasi (X1) & 91 & 30 & 215 & 33 & 0 & 0 & 369 & $\mathrm{M}$ & 0,36 & $-0,91$ \\
\hline $\begin{array}{l}\text { Kondisi petunjuk arah jalan Alun-alun Kota } \\
\text { Bekasi (X2) }\end{array}$ & 38 & 7 & 189 & 102 & 0 & 0 & 336 & M & 0.13 & $-0,68$ \\
\hline $\begin{array}{l}\text { Keberagaman jenis transportasi umum } \\
\text { menuju Alun-alun Kota Bekasi (X3) }\end{array}$ & 92 & 1 & 128 & 115 & 0 & 0 & 336 & M & 0.28 & $-0,65$ \\
\hline $\begin{array}{l}\text { Kondisi parkir di Alun-alun Kota Bekasi } \\
(\mathrm{X} 4)\end{array}$ & 164 & 26 & 86 & 60 & 0 & 0 & 336 & 0 & 0.57 & $-0,74$ \\
\hline $\begin{array}{l}\text { Kondisi pedestrian Alun-alun Kota Bekasi } \\
\text { (X5) }\end{array}$ & 53 & 25 & 186 & 72 & 0 & 0 & 336 & M & 0.23 & $-0,71$ \\
\hline $\begin{array}{l}\text { Kondisi lapangan Alun-alun Kota Bekasi } \\
\text { (X6) }\end{array}$ & 23 & 7 & 203 & 103 & 0 & 0 & 336 & M & 0.09 & $-0,67$ \\
\hline Jenis pohon di Alun-alun Kota Bekasi (X7) & 7 & 229 & 22 & 78 & 0 & 0 & 336 & A & 0.70 & $-0,09$ \\
\hline Kondisi CCTV di Alun-alun Kota Bekasi (X8) & 52 & 173 & 72 & 39 & 0 & 0 & 336 & A & 0,67 & $-0,37$ \\
\hline $\begin{array}{l}\text { Kondisi pagar / bollard Alun-alun Kota } \\
\text { Bekasi (X9) }\end{array}$ & 15 & 154 & 106 & 61 & 0 & 0 & 336 & A & 0,50 & $-0,36$ \\
\hline $\begin{array}{l}\text { Kondisi papan peringatan Alun-alun Kota } \\
\text { Bekasi (X10) }\end{array}$ & 4 & 8 & 126 & 198 & 0 & 0 & 336 & I & 0.04 & $-0,39$ \\
\hline $\begin{array}{l}\text { Kondisi tempat sampah Alun-alun Kota } \\
\text { Bekasi (X11) }\end{array}$ & 67 & 0 & 157 & 112 & 0 & 0 & 336 & $\mathrm{M}$ & 0.20 & $-0,67$ \\
\hline $\begin{array}{l}\text { Kondisi tempat duduk Alun-lun Kota Bekasi } \\
\text { (X12) }\end{array}$ & 67 & 8 & 165 & 96 & 0 & 0 & 336 & M & 0.22 & $-0,69$ \\
\hline $\begin{array}{l}\text { Kondisi penerangan Alun-alun Kota Bekasi } \\
\text { (X13) }\end{array}$ & 11 & 10 & 201 & 114 & 0 & 0 & 336 & M & 0.06 & $-0,63$ \\
\hline $\begin{array}{l}\text { Kondisi toilet di Alun-Alun Kota Bekasi } \\
\text { (X14) }\end{array}$ & 63 & 53 & 220 & 0 & 0 & 0 & 336 & $\mathrm{M}$ & 0,35 & $-0,84$ \\
\hline Kondisi trek larAlun-alun Kota Bekasi (X15) & 49 & 0 & 148 & 139 & 0 & 0 & 336 & $\mathrm{M}$ & 0.15 & $-0,59$ \\
\hline Kondisi kios di Alun-alun Kota Bekasi (X16) & 81 & 52 & 203 & 0 & 0 & 0 & 336 & $\mathrm{M}$ & 0,40 & $-0,85$ \\
\hline $\begin{array}{l}\text { Kondisi anak di Alun-alun Kota Bekasi } \\
\text { (X17) }\end{array}$ & 18 & 175 & 7 & 136 & 0 & 0 & 336 & A & 0.62 & $-0,07$ \\
\hline $\begin{array}{l}\text { Kondisi panggung Alun-alun Kota Bekasi } \\
\text { (X18) }\end{array}$ & 19 & 76 & 49 & 192 & 0 & 0 & 336 & I & 0.28 & $-0,20$ \\
\hline $\begin{array}{l}\text { Kondisi kolam di Alun-alun Kota Bekasi } \\
\text { (X19) }\end{array}$ & 57 & 202 & 33 & 44 & 0 & 0 & 336 & A & 0,77 & $-0,27$ \\
\hline $\begin{array}{l}\text { Keberagaman jenis aktivitas yang dilakukan } \\
\text { pengguna Alun-alun Kota Bekasi (X20) }\end{array}$ & 149 & 24 & 94 & 69 & 0 & 0 & 336 & 0 & 0.51 & $-0,72$ \\
\hline Keberagaman usia pengguna (X21) & 43 & 161 & 36 & 96 & 0 & 0 & 336 & A & 0.61 & $-0,24$ \\
\hline $\begin{array}{l}\text { Durasi pengguna dalam melakukan } \\
\text { aktivitas di Alun-alun Kota Bekasi (X22) }\end{array}$ & 0 & 45 & 20 & 271 & 0 & 0 & 336 & I & 0.13 & $-0,06$ \\
\hline $\begin{array}{l}\text { Keberagaman jenis kelamin pengguna Alun- } \\
\text { alun Kota Bekasi (X23) }\end{array}$ & 166 & 74 & 77 & 19 & 0 & 0 & 336 & 0 & 0.71 & $-0,72$ \\
\hline Variasi penggunaan aktivitas (X24) & 212 & 39 & 20 & 65 & 0 & 0 & 336 & 0 & 0.75 & $-0,69$ \\
\hline $\begin{array}{l}\text { Pengguna Alun-alun Kota Bekasi melakukan } \\
\text { aktivitas secara berkelompok (X25) }\end{array}$ & 20 & 22 & 212 & 82 & 0 & 0 & 336 & M & 0.13 & $-0,69$ \\
\hline $\begin{array}{l}\text { Pengguna melakukan aktivitas berbincang- } \\
\text { bincang dengan pengguna lain nya (X26) }\end{array}$ & 13 & 163 & 16 & 144 & 0 & 0 & 336 & A & 0.52 & $-0,09$ \\
\hline $\begin{array}{l}\text { Seluruh area Alun-alun Kota Bekasi } \\
\text { dimanfaatkan pengguna sepanjang hari } \\
\text { (X27) }\end{array}$ & 147 & 41 & 73 & 75 & 0 & 0 & 336 & 0 & 0.56 & $-0,65$ \\
\hline $\begin{array}{l}\text { Pengunjung Alun-alun Kota Bekasi } \\
\text { membawa serta keluarga/ teman untuk } \\
\text { beraktivitas di Alun-alun Kota Bekasi (X28) }\end{array}$ & 16 & 18 & 17 & 217 & 0 & 0 & 268 & I & 0.13 & $-0,12$ \\
\hline
\end{tabular}


Berdasarkan Tabel 5, dijelaskan bahwa tersedianya kategori one dimensional akan meningkatkan kepuasan pengguna. Namuun, jika tidak tersedia akan menurunkan kepuasan pengguna. Tersedianya kategori must be tidak akan meningkatkan kepuasan para pengguna. Namun, jika tidak tersedia dapat menurunkan tingkat kepuasan pengguna. Tersedianya kategori attractive dapat meningkatkan kepuasan para pengguna. Namun, jika tidak tersedia tidak akan menurunkan tingkat kepuasan pengguna. Ada tidaknya atribut pada kategori indifferent tidak berpengaruh pada kepuasan pengguna. Koefisien tingkat kepuasan nilai better berkisar antara 0 sampai dengan 1, semakin dekat dengan nilai 1 maka semakin tinggi kepuasan pengguna. Koefisien penurunan kepuasan nilai worse berkisar antara 0 sampai dengan -1, semakin mendekati angka -1 makan kekecewaan pengguna semakin kuat.

\subsubsection{Penentuan Prioritas Konsep Penataan untuk Masing-masing Atribut}

Urutan skala prioritas masing-masing kategori adalah Must be > One dimensional > Attractive $>$ Indifferent. Penjelasan terhadap penentuan prioritas tiap atribut dijelaskan sebagai berikut (Tabel 6).

Tabel 6. Penentuan Prioritas Konsep Penataan untuk Masing-masing Atribut

\begin{tabular}{|c|c|c|}
\hline Prioritas & Atribut yang Dilakukan Konsep Penataan & $\begin{array}{c}\text { Konsep } \\
\text { penataan }\end{array}$ \\
\hline \multirow{12}{*}{$\begin{array}{l}\text { Prioritas } 1 \text { (Must be), kategori must be } \\
\text { merupakan atribut-atribut yang masuk } \\
\text { prioritas pertama dalam konsep } \\
\text { penataan Alun-alun Kota Bekasi, karena } \\
\text { atribut-atribut tersebut merupakan } \\
\text { atribut dasar yang mutlak } \\
\text { ketersediaanya bagi Alun-alun Kota } \\
\text { Bekasi. Ketiadaan atribut-atribut yang } \\
\text { masuk kategori must be dapat } \\
\text { menurunkan kepuasan pengguna secara } \\
\text { keseluruhan terhadap Alun-alun Kota } \\
\text { Bekasi }\end{array}$} & Kondisi jalan di Alun-alun Kota Bekasi (X1) & \multirow{12}{*}{$\begin{array}{l}\text { Penyediaan } \\
\text { seluruh } \\
\text { atribut }\end{array}$} \\
\hline & $\begin{array}{l}\text { Kondisi petunjuk arah jalan menuju Alun-alun Kota Bekasi } \\
\text { (X2) }\end{array}$ & \\
\hline & $\begin{array}{l}\text { Keberagaman jenis transportasi umum menuju Alun-alun } \\
\text { Kota Bekasi (X3) }\end{array}$ & \\
\hline & Kondisi pedestrian di Alun-alun Kota Bekasi (X5) & \\
\hline & Kondisi lapangan di Alun-alun Kota Bekasi (X6) & \\
\hline & Kondisi tempat sampah di Alun-alun Kota Bekasi (X11) & \\
\hline & Kondisi tempat duduk di Alun-lun Kota Bekasi (X12) & \\
\hline & Kondisi lampu penerangan di Alun-alun Kota Bekasi (X13) & \\
\hline & Kondisi toilet di Alun-Alun Kota Bekasi (X14) & \\
\hline & Kondisi trek lari di Alun-alun Kota Bekasi (X15) & \\
\hline & Kondisi kios di Alun-alun Kota Bekasi (X16) & \\
\hline & $\begin{array}{l}\text { Penggunaan aktivitas secara berkelompok oleh pengguna } \\
\text { Alun-alun Kota Bekasi (X25) }\end{array}$ & \\
\hline \multirow{5}{*}{$\begin{array}{l}\text { Prioritas } 2 \text { (One dimensional), kategori } \\
\text { one dimensional merupakan atribut } \\
\text { kompetitif. Apabila atribut-atribut } \\
\text { tersebut tidak tersedia, maka Alun-alun } \\
\text { Kota Bekasi tidak akan diminati oleh } \\
\text { para pengguna. Kualitas implementasi } \\
\text { fitur adalah poin utama dalam kategori } \\
\text { ini. }\end{array}$} & Kondisi parkir di Alun-alun Kota Bekasi (X4) & \multirow{5}{*}{$\begin{array}{l}\text { Peningkatan } \\
\text { kualitas } \\
\text { atribut }\end{array}$} \\
\hline & $\begin{array}{l}\text { Keberagaman jenis aktivitas yang dilakukan pengguna } \\
\text { Alun-alun Kota Bekasi (X20) }\end{array}$ & \\
\hline & Keberagaman jenis kelamin pengguna (X23) & \\
\hline & Variasi aktivitas di Alun-alun Kota Bekasi (X24) & \\
\hline & $\begin{array}{l}\text { Alun-alun Kota Bekasi dimanfaatkan oleh pengujung } \\
\text { sepanjang hari (X27) }\end{array}$ & \\
\hline \multirow{5}{*}{$\begin{array}{l}\text { Prioritas } 3 \text { (Attractive), kategori } \\
\text { attractive merupakan pembeda Alun- } \\
\text { alun Kota Bekasi dengan RTH lain dan } \\
\text { tidak selalu dituntut ada oleh para } \\
\text { pengguna. Atribut-atribut attractive yang } \\
\text { dipilih adalah atribut dengan nilai better } \\
\text { diatas 0,60 yang menandakan sebuah } \\
\text { atribut telah lebih dari cukup } \\
\text { meningkatkan kepuasan pengguna }\end{array}$} & Jenis pohon di Alun-alun Kota Bekasi (X7) & \multirow{5}{*}{$\begin{array}{l}\text { Penyediaan } \\
\text { atribut- } \\
\text { dengan fitur } \\
\text { yang } \\
\text { beragam }\end{array}$} \\
\hline & Kondisi CCTV di Alun-alun Kota Bekasi (X8) & \\
\hline & $\begin{array}{l}\text { Kondisi arena bermain anak di Alun-alun Kota Bekasi } \\
\text { (X17) }\end{array}$ & \\
\hline & Kondisi kolam di Alun-alun Kota Bekasi (X19) & \\
\hline & $\begin{array}{l}\text { Keberagaman kelompok usia pengguna Alun-alun Kota } \\
\text { Bekasi (X21) }\end{array}$ & \\
\hline $\begin{array}{l}\text { Prioritas } 4 \text { (Indifferent), kategori } \\
\text { indifferent tidak akan dilakukan konsep, } \\
\text { karena kategori indifferent memiliki } \\
\text { pengaruh yang kecil terhadap kepuasan } \\
\text { dan ketidakpuasan pengguna }\end{array}$ & $\begin{array}{l}\text { Tidak terdapat atribut pada kategori ini yang dilakukan } \\
\text { konsep penataan }\end{array}$ & $\begin{array}{l}\text { Tidak } \\
\text { dilakukan } \\
\text { konsep } \\
\text { penatan }\end{array}$ \\
\hline
\end{tabular}




\subsubsection{Penentuan Konsep Penataan untuk Masing-masing Atribut}

Konsep penataan Alun-alun Kota Bekasi dirumuskan dengan menggabungkan hasil analisis kano, hasil kualitas fisik, hasil kualitas pengguna, kondisi eksisting masing-masing atribut, dan persepsi pengguna dengan menggunakan tabel persandingan. Skema penentuan konsep penataan dijelaskan sebagai berikut (Gambar 3).

\begin{tabular}{|c|c|c|c|c|}
\hline ATRIBUT & PRIORITAS & KONDISI EKSISTING & KUALITAS & $\begin{array}{l}\text { KONSEP } \\
\text { PENATAAN }\end{array}$ \\
\hline $\begin{array}{l}\text { Kondisi } \\
\text { arena } \\
\text { bermain } \\
\text { anak di } \\
\text { Alun-alun } \\
\text { Kota } \\
\text { Bekasi } \\
\text { (X17) }\end{array}$ & $\begin{array}{l}\text { Prioritas } 3 \\
\text { (Attractive) }\end{array}$ & $\begin{array}{l}\text { Alun-alun Kota Bekasi memiliki } \\
\text { arena bermain anak yang berisi } \\
\text { jungkat jungkit, ayunan, perosotan, } \\
\text { dan juga mangkok putar. Seluruh } \\
\text { alat permainan di Alun-alun Kota } \\
\text { Bekasi menggunakan bahan metal } \\
\text { halus dan untuk perosotan } \\
\text { menggunakan material plastik. } \\
\text { Permukaan lantai arena bermain } \\
\text { anak berupa batu berkerikil. Alat } \\
\text { permainan ayunan dan jungkat } \\
\text { jungkit mengalami kerusakan fisik } \\
\text { sehingga dapat membahayakan } \\
\text { para penggunanya dan terdapat } \\
\text { coretan akibat aksi vandalisme } \\
\text { pada alat permainan perosotan. }\end{array}$ & $\begin{array}{l}\text { Berdasarkan Hernowo et al. (2017), } \\
\text { dihasilkan pengukuran kualitas terhadap } \\
\text { arena bermain anak sebagai berikut. } \\
\text { - Secara ketersediaan, arena bermain } \\
\text { anak menyediakan berbagai permainan } \\
\text { anak seperti perosotan, jungkat jungkit, } \\
\text { alat panjat mini, dan ayunan. } \\
\text { - Secara kondisi fisik, permainan anak } \\
\text { terbuat dari bahan plastik/metal dengan } \\
\text { permukaan yang halus dan permukaan } \\
\text { lantai menggunakan pasir tanah. } \\
\text { Secara keterawatan, alat permainan } \\
\text { terbebas dari kerusakan fisik dan } \\
\text { terbebas dari aksi vandalisme berupa } \\
\text { coretan. }\end{array}$ & $\begin{array}{l}\text { Konsep } \\
\text { penataan } \\
\text { untuk atribut } \\
\text { kondisi arena } \\
\text { bermain anak: } \\
\text { - Penyediaan } \\
\text { variasi jenis } \\
\text { alat } \\
\text { permainan } \\
\text { anak di } \\
\text { Taman Kota } \\
\text { Bekasi }\end{array}$ \\
\hline
\end{tabular}

Gambar 3. Contoh Skema Penentuan Konsep Penataan Alun-alun Kota Bekasi

Hasil dari tabel persandingan yang digunakan untuk menentukan konsep penataan terhadap masing-masing atribut diimplementasikan dalam bentuk siteplan hasil konsep penataan Alun-alun Kota Bekasi sebagai berikut (Gambar 4 dan 5).
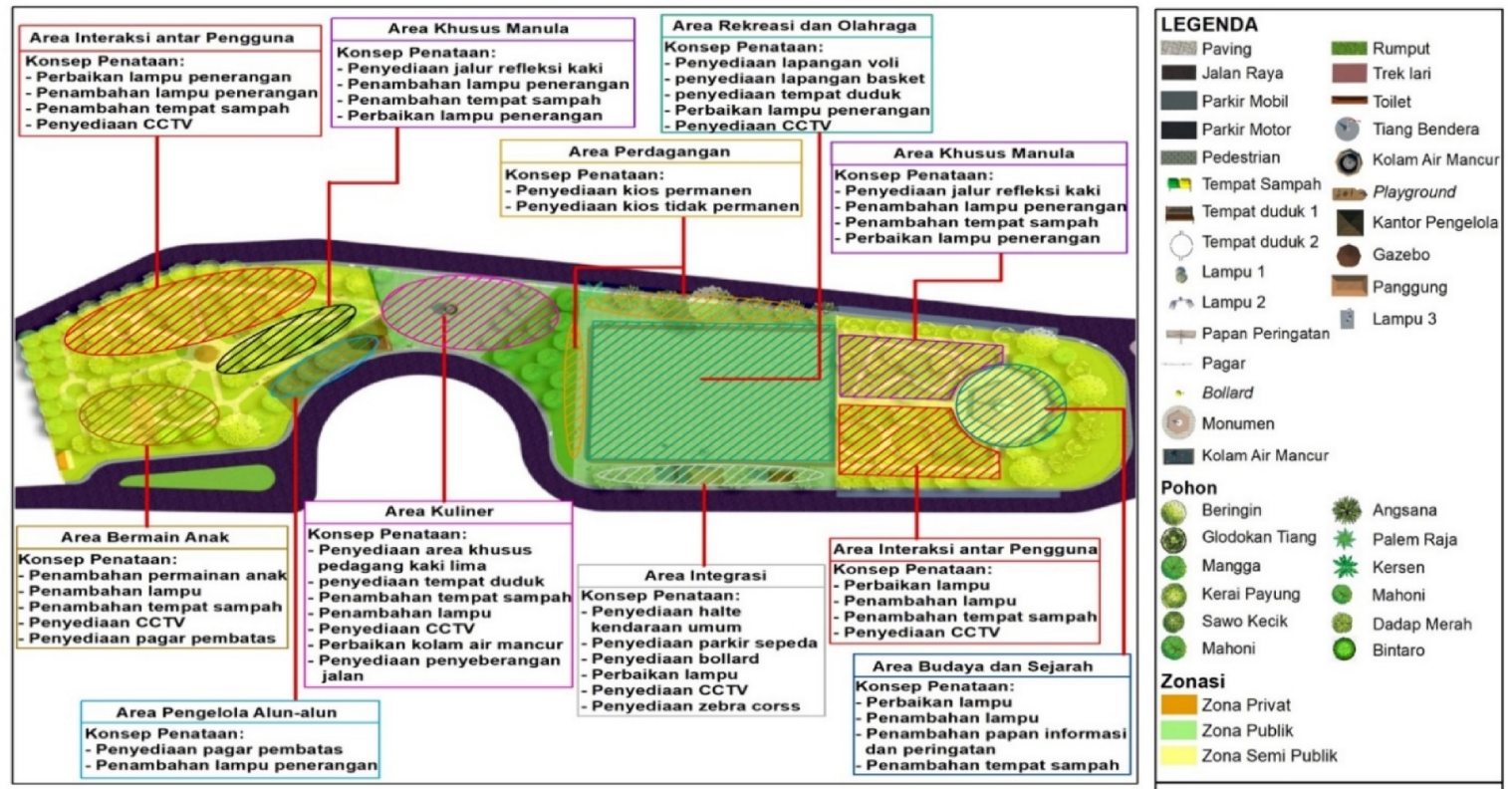

Gambar 4. Peta Konsep Penataan Alun-alun Kota Bekasi 


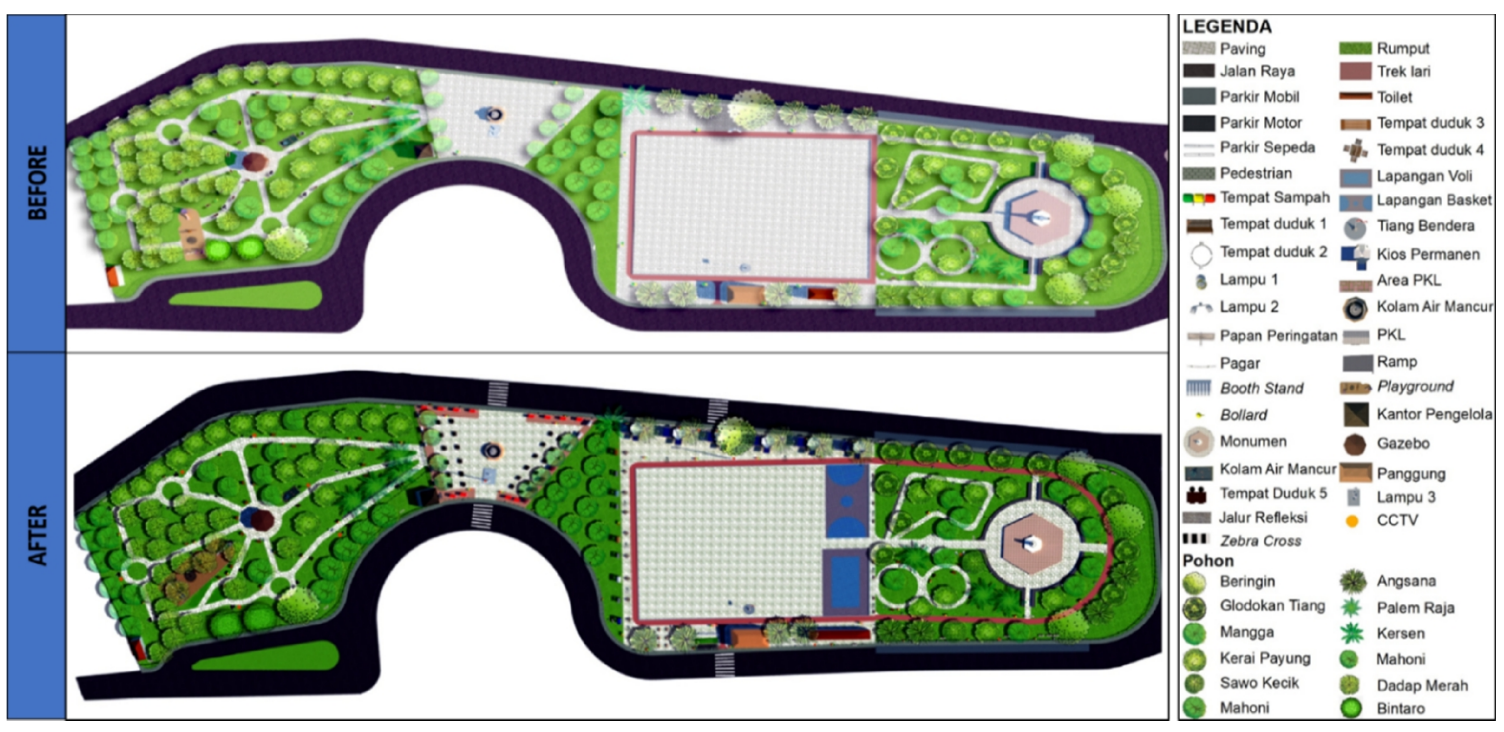

Gambar 5. Siteplan Hasil Konsep Penataan Alun-alun Kota Bekasi

\section{Kesimpulan}

Hasil dari penelitian berjudul Konsep Penataan Ruang Terbuka Publik berdasarkan Pola Aktivitas Pengguna (Studi Kasus di Alun-alun Kota Bekasi) didapatkan beberapa kesimpulan sebagai berikut.

a. $\quad$ Terdapat 3 atribut fasilitas dengan kualitas fisik yang baik karena telah sesuai dengan standar yang telah ditetapkan. Ketiga fasilitas tersebut yaitu papan peringatan, panggung terbuka, dan transportasi umum. Kualitas fisik 16 atribut fasilitas lainnya belum memiliki kesesuaian dengan standar yang telah ditetapkan.

b. Hasil kualitas pemanfaatan ruang, dihasilkan kategori tinggi untuk durasi aktivitas $(0,84)$, keragaman aktivitas $(0,77)$, variasi penggunaan $(0,84)$, dan keberagaman pengguna $(0,83)$. kategori sedang didapatkan oleh intensitas penggunaan aktivitas $(0,58)$ dan intensitas penggunaan aktivitas sosial $(0,51)$.

c. Hasil analisis kano menunjukan bahwa terdapat 12 atribut yang masuk ke dalam prioritas 1, terdapat 5 atribut yang masuk ke dalam prioritas 2, terdapat 5 atribut yang masuk prioritas 3, dan terdapat 4 atribut yang masuk prioritas 4 . Secara umum konsep penataan Alun-alun Kota Bekasi yang dilakukan berupa penyediaan atribut, peningkatan kualitas dan penyediaan keberagaman atribut.

\section{Daftar Pustaka}

Asosiasi Toilet Indonesia. (2016). Understanding of Public Toilet. Full Day Training Toilet Cleaning Expo Clean 2016.

Berger, C., Robert, Blauth, David, Boger, Christoper Bolster, Gary Burchill, William DuMouchel, Fred Pouliot, Reinhart Reichter, Allan Rubinoff, Diane Shen, Mike Timko \& David Walden. (1993). Kano's Method for Understanding Costumer-defined Quality. Center for Quality of Management Journal. 2(4).

Carr, Stephen, Mark Francis, Leanne G. Rivlin \& Andrew M. Stone. (1992). Public Space. Cambridge: Cambridge University Press.

Dinas Lingkungan Hidup Kota Bekasi. (2019). Laporan Kinerja Instansi Pemerintah Dinas Lingkungan Hidup Kota Bekasi. Kota Bekasi: Dinas Lingkungan Hidup Kota Bekasi.

Dinas Tata Kota Bekasi. (2014). Rupa Ruang Kota Kita. Jurnal Tata Kota. 1(1).

Firmansyah, Rangga. (2016). Adaptabilitas Pada Jalur Pedestrian Rusunawa

Panggungharjo, Sewon, Bantul, Yogyakarta. Jurnal Idealog. 1 (1). 
Gumano, Hendry N., Tomi E. \& Hamdi Nur. (2016). Kajian Tingkat Efektifitas Ruang Publik yang Tersedia pada Pusat Kota-Kota di Provinsi Sumatera Barat berdasarkan Metode "Good Public Space Index (GPSI)". E-Jurnal Universitas Bung Hatta 1 (3).

Hariyadi, Feri. (2015). Identifikasi Kualitas Fisik Taman Kota sebagai Ruang Terbuka Publik (Kasus Bagian Wilayah Kota I, II, III Kota Semarang). Jurnal Bumi Indonesia. 4 (3).

Hernowo, Edi \& Ardy M.N. (2017). Karakteristik Ruang Publik Terpadu Ramah Anak (RPTRA) Bahari di Kecamatan Cilandak Jakarta Selatan. Jurnal Teknik ITS. 6 (2).

Irawan, J. Dwi, Pedia Aldy \& Muhammad Rijal. (2015). Perancangan Sekolah Internasional Pekanbaru dengan Pendekatan Eko Arsitektur. Jurnal Jom FTeknik. 2 (1).

Parlindungan, Johannes. (2013). Good Public Space Index Teori dan Metode. Malang: University of Brawijaya.

Pemerintah Kota Bekasi. (2017). Revisi Rencana Tata Ruang Wilayah Kota Bekasi Tahun 2011-2031. Kota Bekasi: Pemerintah Kota Bekasi. 